\title{
Reproductive performance of male mice after hypothalamic ghrelin administration
}

\author{
María Belén Poretti ${ }^{1,2}$, Camila Frautschi ${ }^{3}$, Eugenia Luque ${ }^{1}$, Santiago Bianconi ${ }^{2,3}$, \\ Ana Carolina Martini ${ }^{1}$, Graciela Stutz ${ }^{3}$, Laura Vincenti ${ }^{3}$, Maria Emilia Santillán $^{3}$, \\ Marina Ponzio ${ }^{1}$, Helgi B Schiöth ${ }^{2}$, Marta Fiol de Cuneo ${ }^{3}$ and Valeria Paola Carlini ${ }^{1,2}$ \\ ${ }^{1}$ INICSA, Facultad de Ciencias Médicas (CONICET-FCM), Instituto de Fisiología, Córdoba, Argentina, ${ }^{2}$ Department \\ of Neuroscience, Functional Pharmacology, Uppsala University, Uppsala, Sweden and ${ }^{3}$ Facultad de Ciencias \\ Médicas, Universidad Nacional de Córdoba, Cátedra de Fisiología Humana, Córdoba, Argentina
}

Correspondence should be addressed to M B Poretti; Email: mabelen56@hotmail.com

\begin{abstract}
It has been demonstrated that food intake and reproductive physiology are both simultaneously modulated to optimize reproductive success under fluctuating metabolic conditions. Ghrelin (GHRL) is an orexigenic peptide identified as the endogenous ligand of the growth hormone secretagogue receptor that is being investigated for its potential role on reproduction. Considering that data available so far are still limited and characterization of GHRL action mechanism on the reproductive system has not been fully elucidated, we studied the participation of hypothalamus in GHRL effects on sperm functional activity, plasma levels of gonadotropins and histological morphology in mice testes after hypothalamic infusion of 0.3 or $3.0 \mathrm{nmol} / \mathrm{day} \mathrm{GHRL}$ or artificial cerebrospinal fluid (ACSF) at different treatment periods. We found that GHRL $3.0 \mathrm{nmol} /$ day administration for 42 days significantly reduced sperm concentration (GHRL $3.0 \mathrm{nmol} /$ day $=14.05 \pm 2.44 \times 10^{6} / \mathrm{mL}$ vs ACSF $\left.=20.33 \pm 1.35 \times 10^{6} / \mathrm{mL}, P<0.05\right)$ and $\mathrm{motility}$ $($ GHRL $3.0 \mathrm{nmol} / \mathrm{day}=\mathbf{5 9 . 4 0} \pm \mathbf{4 . 2 0} \%$ vs ACSF $=\mathbf{7 5 . 8 0} \pm \mathbf{1 . 4 0} \%, P<\mathbf{0 . 0 5})$. In addition, histological studies showed a significant decrease percentage of spermatogonia (GHRL $3.0 \mathrm{nmol} / \mathrm{day}=6.76 \pm 0.68 \%$ vs ACSF $=9.56 \pm 0.41 \%, P<0.05)$ and sperm $($ GHRL $3.0 \mathrm{nmol} / \mathrm{day}=24.24 \pm 1.92 \%$ vs $\mathrm{ACSF}=31.20 \pm 3.06 \%, P<0.05)$. These results were associated with a significant reduction in luteinizing hormone and testosterone plasma levels $(P<0.05)$. As GHRL is an orexigenic peptide, body weight and food intake were measured. Results showed that GHRL increases both parameters; however, the effect did not last beyond the first week of treatment. Results presented in this work confirm that central GHRL administration impairs spermatogenesis and suggest that this effect is mediated by inhibition of hypothalamic-pituitary-gonadal axis.

Reproduction (2018) 156 121-132
\end{abstract}

\section{Introduction}

Ghrelin (GHRL) is a 28 amino acid acylated peptide, mainly produced by stomach (Kojima et al. 1999) and in smaller quantities by other tissues including reproductive tissues, such as testicular, ovarian, uterine and placental tissues (Horvath et al. 2001, Barreiro et al. 2002, Fernandez-Fernandez et al. 2004).

It has been recently demonstrated that food intake and reproductive physiology are both simultaneously modulated by multiple chemical signals. In this sense, there are many hormonal mediators and/or neuropeptides that optimize reproductive success under fluctuating metabolic conditions. Gonadal steroids affect energy balance and adiposity in a variety of mammalian species; alterations in nutritional status also markedly influence the hypothalamic-pituitary-gonadal (HPG) axis (Casanueva \& Dieguez 1999, Tena-Sempere \& Barreiro 2002). Biological actions recognized for
GHRL are mostly conducted through interaction with its specific cell-surface receptor, GHS-R1a (Gaytan et al. 2004). This receptor is mainly expressed in the arcuate and ventromedial nuclei of the hypothalamus, and it is also present in many peripheral organs (Guan et al. 1997, Kojima et al. 2001, Gnanapavan et al. 2002), indicating multiple GHRL functions on these tissues (Broglio et al. 2003). In this line, it has been demonstrated the expression of GHRL receptor in rat testis (Tena-Sempere et al. 2002, Barreiro et al. 2003). Moreover, in vitro studies indicate a direct inhibitory action of GHRL on testicular testosterone secretion (Tena-Sempere et al. 2002). In this context, an increasing body of evidence demonstrates that GHRL represents an additional regulatory signal in male reproduction (Garcia et al. 2007). Moreover, several lines of evidence suggest that GHRL actions include both systemic effects at different levels of the HPG axis, as well as direct gonadal actions of locally produced GHRL (Barreiro \& 
Tena-Sempere 2004, Kheradmand et al. 2009). However, data available so far are still limited and characterization of GHRL mechanism of action on the reproductive system remains largely unexplored. Therefore, the present work attempted to recognize hypothalamus participation in GHRL effects on spermatogenesis, reproductive hormones levels (luteinizing (LH), folliclestimulating ( $\mathrm{FSH}$ ) and testosterone) and sperm quality in mice.

\section{Materials and methods}

\section{Animals}

Adult male mice (albino Swiss N/NIH), 60 days old with an initial body weight of $\cong 30 \mathrm{~g}$ were used. Colony room was maintained on 14:10-h light-darkness photoperiod and under controlled temperature $\left(24 \pm 2^{\circ} \mathrm{C}\right)$, with pelleted mouse food (Gepsa Feeds, Pilar, Argentina) and water ad libitum.

Experiments were conducted in accordance with the guidelines of the experimental protocol approved by the Committee for the Care and Use of Experimental Animals, School of Medical Sciences, National University of Córdoba (07/07/15).

\section{Surgery}

After 2 weeks of adaptation period in the storage room, ventromedial hypothalamic surgery was carried out using osmotic pumps (Alzet, Durect, Cupertino, CA, USA), according to the methods described by Paxinos and Franklin (2001). Animals were anesthetized using a combination of $55 \mathrm{mg} / \mathrm{kg}$ ketamine $\mathrm{HCl}$ (Vetanarcol König: Laboratories König S.A, Argentina) and $11 \mathrm{mg} / \mathrm{kg}$ xylazine (Kensol König: Laboratories König S.A) and placed in a stereotaxic apparatus. The coordinates relative to bregma were anterior $0.15 \mathrm{~mm}$, lateral $0.05 \mathrm{~mm}$ and vertical $5.5 \mathrm{~mm}$. Cannulae were fixed to the skull surface with dental acrylic cement. Different animals were infused daily with ACSF or GHRL 0.3 or $3.0 \mathrm{nmol} /$ day. After surgery, animals were housed in individual cages.

At the end of the experiments, all brains were subjected to histological analysis to confirm the guide cannula location (Fig. 1). Only animals with correct cannula position were considered for statistical analysis.

\section{Drugs and treatment}

GHRL (acyl-ghrelin) (Innovagen, Sweden) was dissolved in ACSF $(0.3$ or $3.0 \mathrm{nmol} / \mu \mathrm{L})$, divided into aliquots and kept at $-20^{\circ} \mathrm{C}$ until experimental day. GHRL was infused chronically in the hypothalamus employing osmotic pumps model 1007D $(0.5 \mu \mathrm{L} / \mathrm{h}, 7$ days) or model 2006 ( $0.15 \mu \mathrm{L} / \mathrm{h}, 42$ days).

\section{Experimental procedure}

In mouse, spermatogenesis consists in a developmental period of 35 days from differentiated type A1 spermatogonia to spermatozoa (Franca et al. 1998), while each spermatogenic cycle length is 8.6 days (Clermont \& Trott 1969). Taking this
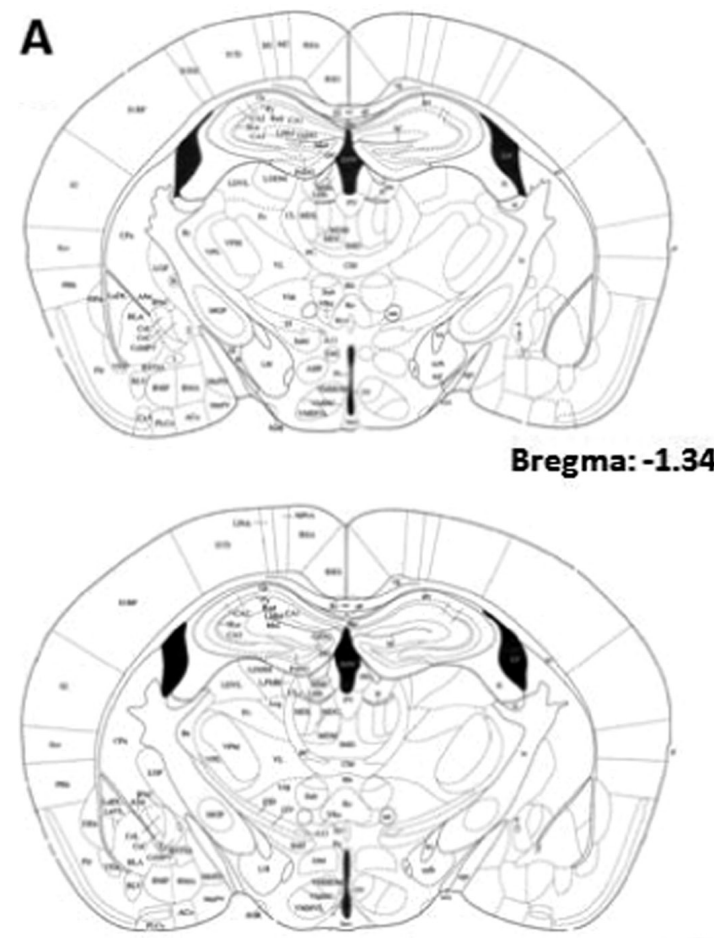

Bregma: -1.46

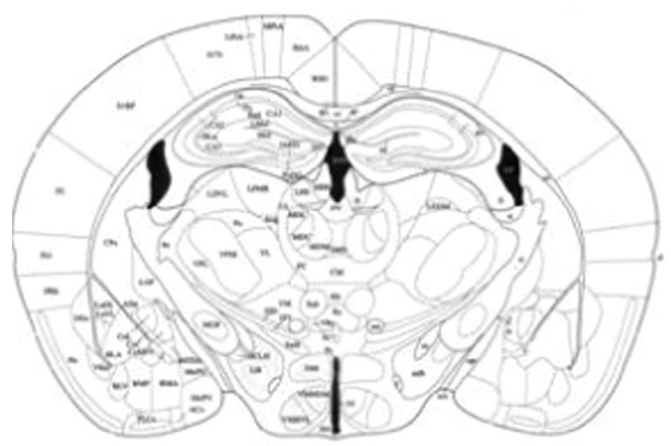

Bregma: -1.58

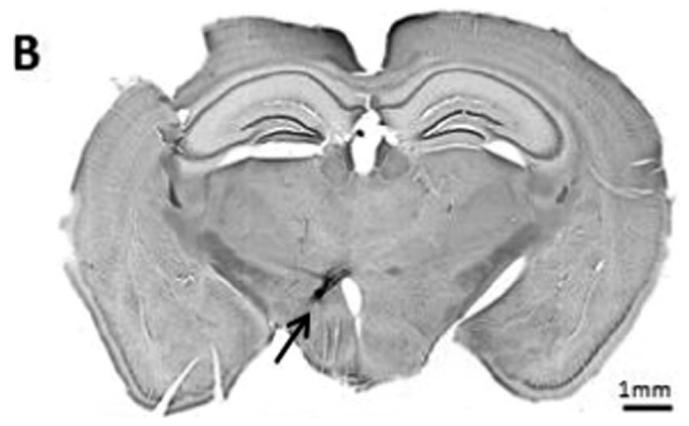

Figure 1 Histological confirmation of cannula location into the hypothalamus. (A) Coronal sections of mice brain based on the atlas of Paxinos and Franklin (2001). Anteroposterior locations relative to the bregma are indicated in each section. (B) Infusion position (arrow) employing osmotic pumps model $2006(0.15 \mu \mathrm{L}$ per hour, 42 days). Photography obtained by spectral confocal microscope (FV1200 OLYMPUS), Ob: 4× with PRIOR motorized stage assembled to software ASW 4.0. Scale bar: $1 \mathrm{~mm}$. 
into account, assessment of GHRL effects on sperm functional activity in mice was carried out using different experimental approaches. Specifically for this purpose, two sets of experiments were performed. They are the following.

First, in order to study hypothalamus participation in GHRL effects on epididymal maturation, animals were treated for 7 days (period that covers the release of mature spermatozoa into the lumen of the seminiferous tubule and a series of cellular modifications that occur during transit along the epididymal tubule).

Second, in order to study hypothalamus participation in GHRL effects on spermatogenesis, animals were treated for 42 days (period that covers at least one complete spermatogenic cycle and epididymal sperm migration).

In order to minimize potential bias of major differences in body weight on the different reproductive endpoints under analysis, food intake and body weight were daily measured in both experimental sets. After treatment, animals were killed by decapitation in a room separate from that in which the other animals were kept. Trunk blood was collected into EDTA tubes and immediately centrifuged (1700 rpm, $\left.10 \mathrm{~min}, 4^{\circ} \mathrm{C}\right)$. Individual plasma samples were frozen and stored (at $-20^{\circ} \mathrm{C}$ ) for subsequent hormonal determination.

Spermatozoa were obtained by making incisions in the isolated caudal portion of the epididymis, allowing the sperm to extrude into $2 \mathrm{~mL}$ of Tyrode medium for $10 \mathrm{~min}$.

Testes were immediately removed and weighed (free of surrounding fat). Weight is expressed as relative weight (testicular weight/animal weight). Histological and ultrastructural studies were then performed in animals treated for 42 days.

\section{Food intake and body weight}

Food intake was determined as the difference between food available and food remainder $24 \mathrm{~h}$ later between 11:00 and 12:00 $\mathrm{h}$ to prevent variations determined by circadian rhythms. Body weight was measured daily. Data are expressed in grams (g) as mean \pm S.E.M. $n=9-12$ animals/group.

\section{Incubation medium}

Modified Tyrode's medium (Fraser 1993) supplemented with $4 \mathrm{mg} / \mathrm{mL}$ of bovine serum albumin (Sigma, St Louis, MO, USA) was employed and gametes were incubated at $37^{\circ} \mathrm{C}$ (5\% CO $\mathrm{CO}_{2}: 95 \%$ air) and 100\% humidity until use.

\section{Reproductive parameters}

Sperm concentration, motility and maturity were measured in a Makler counting chamber (Sefi-Medical Instruments, Haifa, Israel) under an inverted microscope (Olympus CK2) at 200x magnification (Makler 1980). Concentration is expressed in millions of spermatozoa per $\mathrm{mL}$ of sperm suspension. Motility results are expressed as a percentage of motile cells (progressive plus non-progressive spermatozoa). No less than 100 gametes were examined (Fiol de Cuneo et al. 1994). To evaluate sperm maturity, percentages of bending spermatozoa (with a marked flagellar angularity of 90-180 toward the tail in the sperm head or midpiece), spermatozoa with cytoplasmic droplets (a remnant of germ cell cytoplasm in the sperm tail), and those with both characteristics were quantified. $n=9-10$ animals/group.

\section{Sperm viability}

Sperm viability was evaluated by supravital staining with Hoechst 33258 (H258) (3 mg/mL in isotonic solution) (Calbiochem) (Yelian \& Dukelow 1992). Using appropriate ultraviolet fluorescence optics (Axiolab, Zeiss, Germany), spermatozoa showing bright fluorescent nuclei were scored as dead and cells that excluded the $\mathrm{H} 258$ were scored as viable. Viability of at least 100 cells was assessed; results are expressed as a percentage of viable spermatozoa. $n=9-10$ animals/group.

\section{Hypoosmotic swelling test}

As previously described (Ruiz et al. 1996), $0.1 \mathrm{~mL}$ of sperm suspension was mixed with $1 \mathrm{~mL}$ of the hypoosmotic solution $(100 \mathrm{mosmol} / \mathrm{L})$ for $45 \mathrm{~min}\left(37^{\circ} \mathrm{C}\right)$. Evaluations were made by phase-contrast microscopy at a magnification of $400 \times$; 100 or more cells were observed; results are expressed as the percentage of spermatozoa that showed tail swelling ( $n=9-10$ animals/group).

\section{Acrosomal integrity}

Samples were treated as stated by Puechagut et al. (2012). Acrosomal integrity was evaluated with double staining with Pisum sativum agglutinin labeled with fluorescein isothiocyanate (FITC-PSA) (Sigma) and Hoechst 33258. Only viable cells were scored; results are expressed as the percentage of acrosome-intact cells ( $n=9-10$ animals/group).

\section{Hormone assays}

\section{Gonadotropins assay}

Luteinizing hormone and stimulating follicle hormone concentrations in plasma samples were determined using a commercial ELISA kit following the manufacturer's instructions (MyBioSource, USA). The range of detection for the $\mathrm{LH}$ kit was $0.78-50 \mathrm{mlU} / \mathrm{mL}$ and for FSH kit $3.12-100 \mathrm{mIU} / \mathrm{mL}$. The minimum detectable Mouse $\mathrm{LH}$ up to $0.08 \mathrm{mlU} / \mathrm{mL}$ and the lowest detection limit for $\mathrm{FSH}$ was $1.0 \mathrm{mIU} / \mathrm{mL}$. Intra- and interassay coefficients of variation for $\mathrm{LH}$ were $\leq 8 \%$ and $\leq 12 \%$ respectively. Both intra- and interassay coefficients of variation for $\mathrm{FSH}$ were $<15 \%$. Results were expressed in $\mathrm{mIU} / \mathrm{ml} . n=5-7$ animals/group.

\section{Testosterone assay}

Testosterone concentrations in plasma samples were determined by enzyme immunoassay (EIA) test, using polyclonal antibodies, standards and their corresponding horseradish peroxidase conjugates (anti-Testosterone R156/7, Department of Population Health and Reproduction, C. Munro, UC Davis, CA, USA). Antibody cross-reacts with 5 - $\alpha$-dihydrotestosterone $(57.4 \%)$, androstenedione $(0.27 \%)$, androsterone $(0.04 \%)$, cholesterol $(0.03 \%)$ and $<0.02 \%$ with all other steroids tested. Assays were performed according to 
general technique described by Munro and Lasley (1988). Briefly, plasma samples were assayed in duplicate using flatbottom microtiter plates (Nunc Maxisorp, VWR, Mississauga, $\mathrm{ON}$, Canada). Plates were first coated with $50 \mu \mathrm{L}$ of the antibody stock diluted in coating buffer $(50 \mathrm{mM}$ bicarbonate buffer, $\mathrm{pH}$ 9.6, 1:10,500), covered with acetate sealers to prevent evaporation and incubated overnight at $4{ }^{\circ} \mathrm{C}$. After $16-24 \mathrm{~h}$, plates were washed to remove any unbound antibody with $0.02 \%$ Tween 20 solution using a Bio-Tek ELx 405VR microplate washer (Bio-Tek Instruments, Winooski, VT, USA). Immediately after washing, $50 \mu \mathrm{L}$ of samples, standards and controls were added in duplicates, followed by $50 \mu \mathrm{L}$ of horseradish peroxidase conjugate diluted in EIA buffer $(1: 20,000)$. Plates were then covered and incubated at room temperature $\left(21^{\circ} \mathrm{C}\right)$ for $2 \mathrm{~h}$. Following incubation, the plates were washed and blotted dry, and $100 \mu \mathrm{l}$ of substrate solution $(50 \mathrm{mM}$ citrate, $1.6 \mathrm{mM}$ hydrogen peroxide and $0.4 \mathrm{mM}$ 2,20-azino-di-(3-ethylbenzthiazoline sulfonic acid) diammonium salt, $\mathrm{pH}$ 4.0) were added to each well (Munro et al. 1991). Absorbance was measured at $405 \mathrm{~nm}$ using a microplate reader (Thermo Electron Corporation, Thermo Fisher Scientific, Waltham, MA, USA). Accepted intra- and interassay coefficients of variation for the high and low control samples were $<10$ and $<15 \%$, respectively, in all hormonal determinations. Assay sensitivity was $2.4 \mathrm{pg} / \mathrm{well}$. Results were expressed as Log10 of the plasma testosterone concentration in $\mathrm{ng} / \mathrm{mL}$ ( $n=9-10$ animals/group).

\section{Testicular histology}

Testes were fixed in Bouin's solution for $48 \mathrm{~h}$, dehydrated and embedded in paraffin. Histological sections $(5 \mathrm{~mm})$ were stained with hematoxylin and eosin (H\&E). All sections were observed with optical Zeiss Primo Star trinocular microscope (Gottingen, Germany) connected to Zeiss Axio Cam ERc 5s digital camera. The H\&E-stained sections were used to identify different stages of the seminiferous epithelium cycle, Leydig and Sertoli cells. Differential cell counts were gathered from every 20th section to provide a 5\% sample selection per testis. Histomorphometry was conducted by counting of 20 seminiferous tubules in each slide (Kheradmand et al. 2009). Results are expressed as percentage of each germ cell type per animal and Leydig and Sertoli cells as number of cell per animal ( $n=5$ animals/group).

Testicular morphometry analyses were performed taking into account 50 round or nearly round seminiferous tubules from each mouse (Duan et al. 2014). Seminiferous tubular diameter and epithelium height were measured with AxioVision 4.0 $\mathrm{V}$ 4.8.2.0 image analysis system. Results are expressed in micrometers ( $n=5$ animals/group).

\section{Transmission electron microscopy}

As stated by Diaz de Barboza (2014), testes were fixed by immersion in a mixture of $2 \%(\mathrm{v} / \mathrm{v})$ glutaraldehyde and $4 \%$ $(\mathrm{v} / \mathrm{v})$ formaldehyde in $0.1 \mathrm{M}$ cacodylate buffer, treated with $1 \% \mathrm{w} / \mathrm{v}$ osmium tetroxide for $2 \mathrm{~h}$, dehydrated and embedded in Araldite resin at $60^{\circ} \mathrm{C}$ for $48 \mathrm{~h}$. For ultrastructural studies, thin sections were cut with a diamond knife on a JEOL JUM-7 ultramicrotome and examined in a Zeiss LEO-906E electron microscope (Oberkochen, Germany) ( $n=3-5$ animals/group).

\section{Statistical analysis}

Data were analyzed using STATISTICA - Stat Soft (version 10) statistical package. Normality and homogeneity of variances were corroborated; when statistical assumptions were violated, data were transformed to Log10. Data are expressed as mean \pm S.E.M.; $P$ values lower than 0.05 were considered statistically significant.

Reproductive parameters and hormone assays data were analyzed by one-way ANOVA and LSD test for post hoc comparison was performed when appropriate. When data were expressed as percentages, they were analyzed using chisquare test.

Food intake and body weight data were analyzed using a repeated-measure ANOVA and LSD post hoc test was performed when appropriate.

Differential cell counts from histological data were analyzed by multi-way ANOVA and LSD post hoc test was performed when appropriate.

\section{Results}

\section{Food intake and body weight}

Effects of 7-day hypothalamic GHRL administration on mice food intake and body weight

Quantification of food intake carried out during the experimental period is shown in Fig. 2A. As can be seen, GHRL $3.0 \mathrm{nmol} /$ day treatment induced significant differences in the amount of daily food consumed only between the second and the fifth day of treatment $(P<0.05)$. Repeated-measures ANOVA also revealed a significant interaction between treatment and time $(F=2.60, d f=12, P<0.05)$, significant effects of treatment $(F=6.73, d f=2, P<0.05)$ and significant effects of time $(F=51.70, d f=6, P<0.05)$.

In relation to body weight (Fig. 2B), the higher intrahypothalamic GHRL dose employed for 7 days induced significant change on body weight at the end of treatment (ACSF: $33.16 \pm 0.81 \mathrm{~g}, n=11 \mathrm{vs}$ GHRL $3.0: 39.95 \pm 1.17 \mathrm{~g}$, $n=9$ animals/group; $F=7.89, d f=2, P<0.05)$.

Effects of 42-day hypothalamic GHRL administration on mice food intake and body weight

Quantification of food intake carried out daily during the experimental period is shown as weekly food intake in Fig. 3A. Repeated-measures ANOVA test revealed a significant interaction between GHRL treatment and time $(F=3.72, d f=10, P<0.05)$, significant effects of time $(F=10.65, d f=5, \quad P<0.05)$ and no significant effects of treatment $(P>0.05)$. As can be seen, GHRL $3.0 \mathrm{nmol} /$ day treatment induced significant increase in the amount of food consumed only during the first week of treatment $(P<0.05)$. 


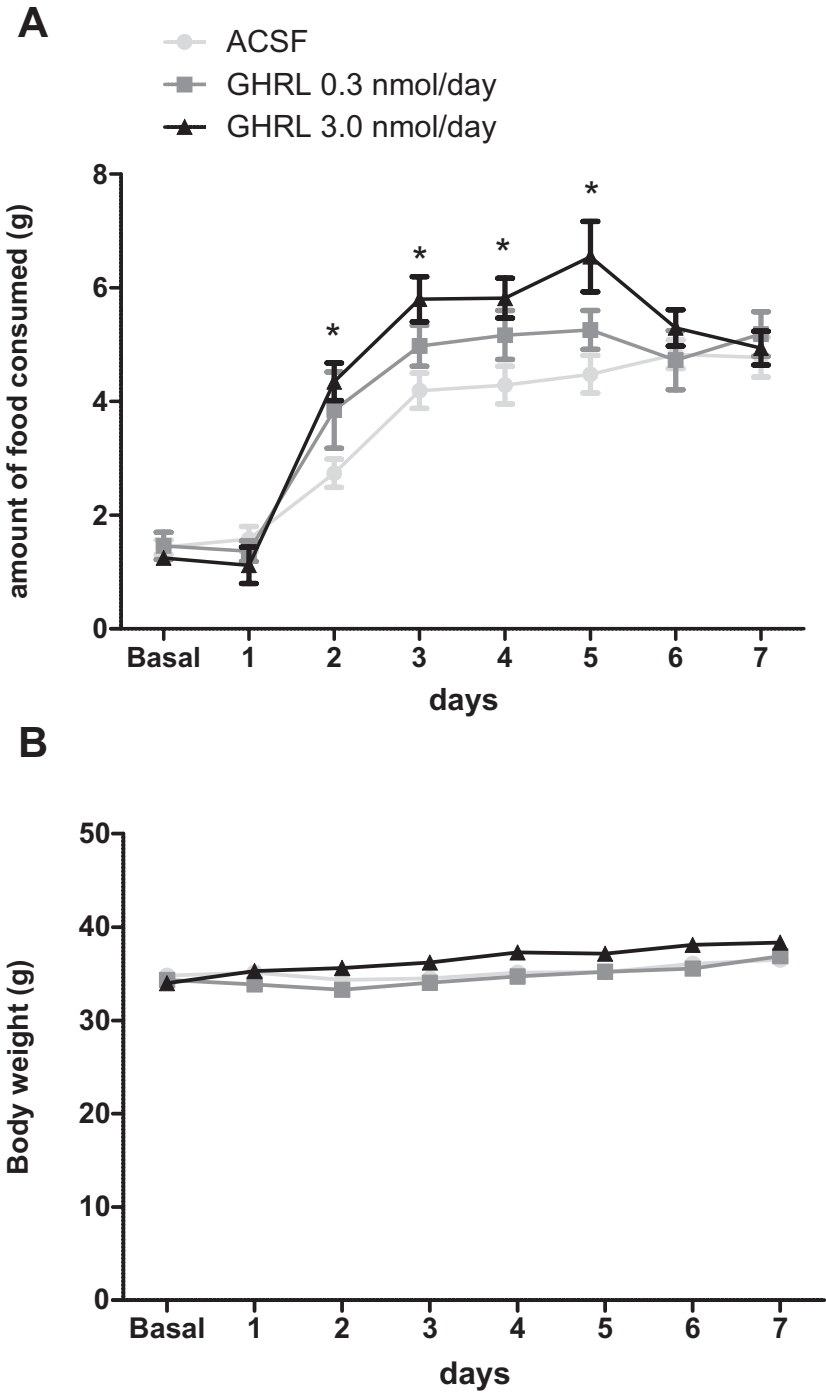

Figure 2 Ghrelin (GHRL) effect on daily food intake (A) and body weight (B) in mice chronically treated for 7 days (mean $(g) \pm$ S.E.M.). Animals were infused into hypothalamus with GHRL or artificial cerebrospinal fluid (ACSF) employing osmotic pumps model 1007D $\left(0.5 \mu \mathrm{L}\right.$ per hour, 7 days). $n=9-12$ animals/group. ${ }^{*}$ Significant differences in comparison to ACSF animals, $P<0.05$.

Concordantly with increased food intake, a significant increase in body weight in GHRL $3.0 \mathrm{nmol} /$ day vs ACSF group was detected only in the first week of treatment (Fig. 3B) $(F=2.98, d f=2, P<0.05)$. However, no significant variations were found between final and initial weight for each animal $(P>0.05)$.

\section{Reproductive parameters}

Effects of 7-day hypothalamic GHRL administration on mice sperm functional activity

Evaluation of seminal parameters showed no significant modification in the parameters evaluated between groups (sperm concentration, motility, viability, response
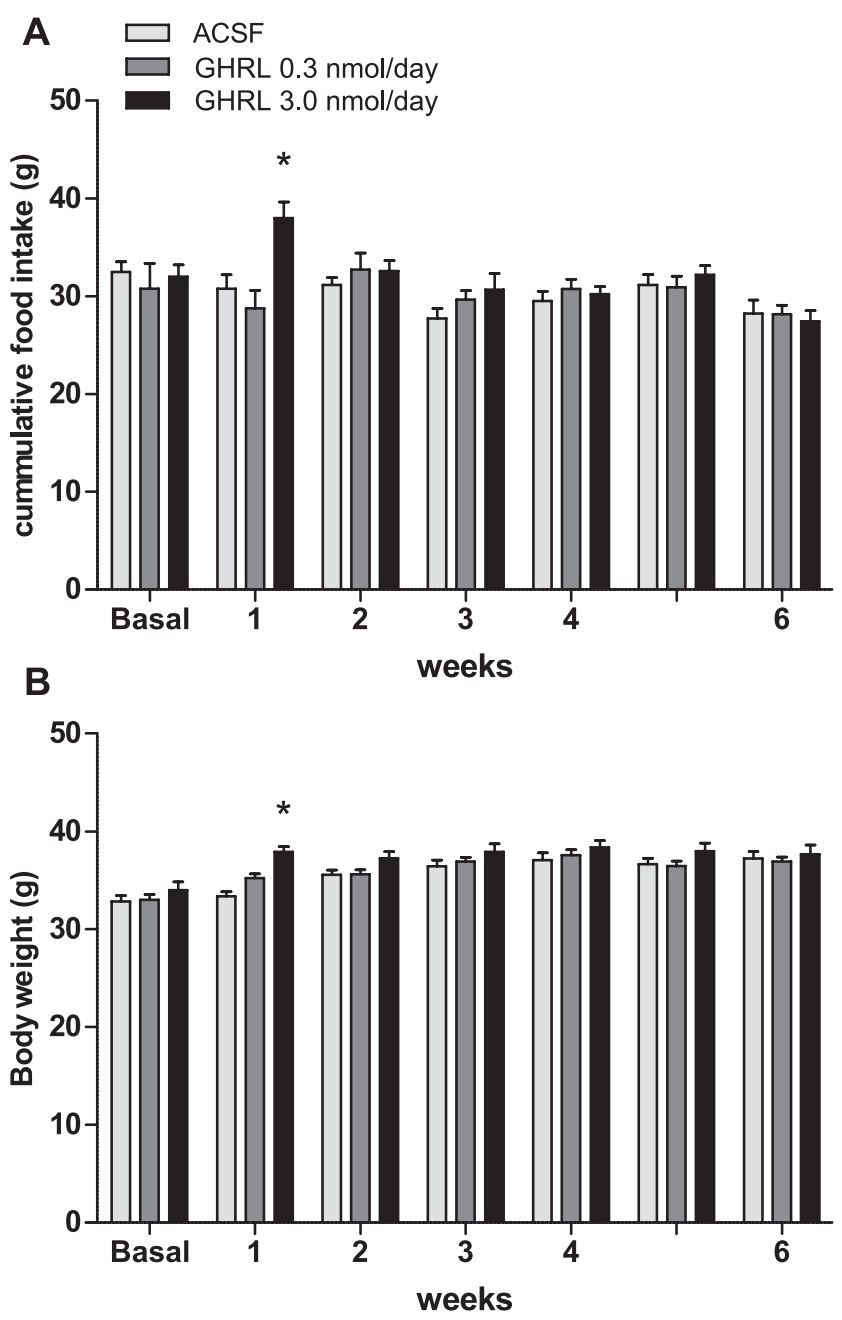

Figure 3 Ghrelin (GHRL) effect on weekly cumulative food intake (A) and body weight $(B)$ in mice chronically treated for 42 days (mean (g) \pm S.E.M.). Animals were infused into hypothalamus with GHRL or artificial cerebrospinal fluid (ACSF) employing osmotic pumps model $2006(0.15 \mu \mathrm{L} / \mathrm{h}, 42$ days). $n=9-10$ animals/group. *Significant differences in comparison to ACSF animals, $P<0.05$.

to hypoosmotic shock and acrosomal integrity, $P>0.05)$. Moreover, there were no significant differences in sperm maturity parameters like percentages of bending spermatozoa, spermatozoa with cytoplasmic droplets or those with both characteristics (Table 1).

Relative testicular weights were similar in all the three groups $(4.97 \pm 0.20 ; 5.79 \pm 0.12,5.54 \pm 0.16 \mathrm{mg}$ in ACSF, GHRL 0.3 and GHRL $3.0 \mathrm{nmol} /$ day animals respectively).

Effects of 42-day hypothalamic GHRL administration on mice sperm functional activity

Figure 4 shows the effects of hypothalamic GHRL treatment for 42 days on sperm concentration (upper panel) and percentage of sperm motility (lower panel), respectively. As can be seen, GHRL $3.0 \mathrm{nmol} /$ day significantly reduces sperm concentration $(F=3.93$, 
Table 1 Functional activity of caudal epididymis sperm from mice treated for 7 days with artificial cerebrospinal fluid or Ghrelin.

\begin{tabular}{lrrr}
\hline & ACSF & GHRL $(0.3 \mathrm{nmol} /$ day $)$ & GHRL $(3.0 \mathrm{nmol} /$ day $)$ \\
\hline Sperm concentration $\left(1 \times 10^{6} / \mathrm{mL}\right)$ & $23.59 \pm 1.90$ & $18.53 \pm 2.06$ & $25.11 \pm 6.11$ \\
Motility $(\%)$ & $75.00 \pm 5.25$ & $81.80 \pm 2.24$ & $76.94 \pm 2.45$ \\
Viability $(\%)$ & $75.89 \pm 5.78$ & $77.50 \pm 5.09$ & $87.89 \pm 1.84$ \\
Hypoosmotic swelling test $(\%)$ & $74.72 \pm 3.62$ & $80.82 \pm 1.60$ & $79.56 \pm 1.94$ \\
Acrosomal integrity $(\%)$ & $67.89 \pm 6.77$ & $67.40 \pm 6.70$ & $78.67 \pm 6.28$ \\
Bending $(\%)$ & $2.67 \pm 0.85$ & $4.40 \pm 1.63$ & $3.28 \pm 0.68$ \\
Cytoplasmic droplets $(\%)$ & $11.17 \pm 2.50$ & $13.10 \pm 3.52$ & $15.00 \pm 5.96$ \\
\hline
\end{tabular}

Animals were infused with Ghrelin (GHRL) or artificial cerebrospinal fluid (ACSF) into hypothalamus employing osmotic pumps model 1007D $(0.5 \mu \mathrm{L} / \mathrm{h}, 7$ days). Results are expressed as mean \pm S.E.M. $n=9-10$ animals/group.

$d f=2, P<0.05)$ and motility $(F=12.82, d f=2, P<0.05)$. There were no significant differences between groups in the other parameters evaluated (viability, response to hypoosmotic shock and acrosomal integrity) (Table 2).

\section{GHRL effect on plasma levels of gonadotropins in mice chronically treated for 7 or 42 days}

Figure 5 shows GHRL effect on FSH plasma levels in animals treated for 7 (Fig. 5A) or 42 (Fig. 5B) days. Similar FSH plasma levels were observed in animals treated with GHRL in relation to ACSF administered mice $(P>0.05)$.

Figure 6 shows GHRL effect on plasma LH levels in animals treated for 7 (Fig. 6A) or 42 (Fig. 6B) days. As can be seen, 7-day treatment produced no significant changes in plasma LH levels $(P>0.05)$ while GHRL $3.0 \mathrm{nmol} /$ day treatment for 42 days significantly reduced this variable $(F=4.21, d f=2, P<0.05)$.

\section{GHRL effect on plasma testosterone levels in mice chronically treated for 7 or $\mathbf{4 2}$ days}

Figure 7 shows GHRL effect on plasma testosterone levels in animals treated for 7 (Fig. 7A) or 42 (Fig. 7B) days. As can be seen, 7-day treatment produced no significant changes in testosterone plasma levels $(P>0.05)$ while GHRL $3.0 \mathrm{nmol} /$ day treatment for 42 days significantly reduced this variable $(F=4.98, d f=2, P<0.05)$.

In line with results previously presented, linear correlation analysis showed significant correlation between epididymal spermatozoa concentration $\left(10^{6} \mathrm{cells} / \mathrm{mL}\right)$ and the $\log 10$ of plasma testosterone concentration $(\mathrm{ng} / \mathrm{mL})(r=0.8386)$ and between sperm motility $(\%)$ and the $\log 10$ of plasma testosterone concentration (ng/mL) $(r=0.8031)$ (Fig. 8).

\section{Testicular histology and ultrastructural morphology}

Effects of 42-day hypothalamic GHRL administration on mice testicular histology

Figure 9 shows GHRL effect on cell spermatic cycle. As can be seen, only GHRL $3.0 \mathrm{nmol} /$ day treatment induced significant decrease in the percentage of spermatogonia and sperm $(F=3841.96, d f=4, P<0.05)$ and an increase in the intermediate stages, spermatocytes and spermatids $(P<0.05)$. There were no significant differences between GHRL doses $(P>0.05)$. No significant differences were
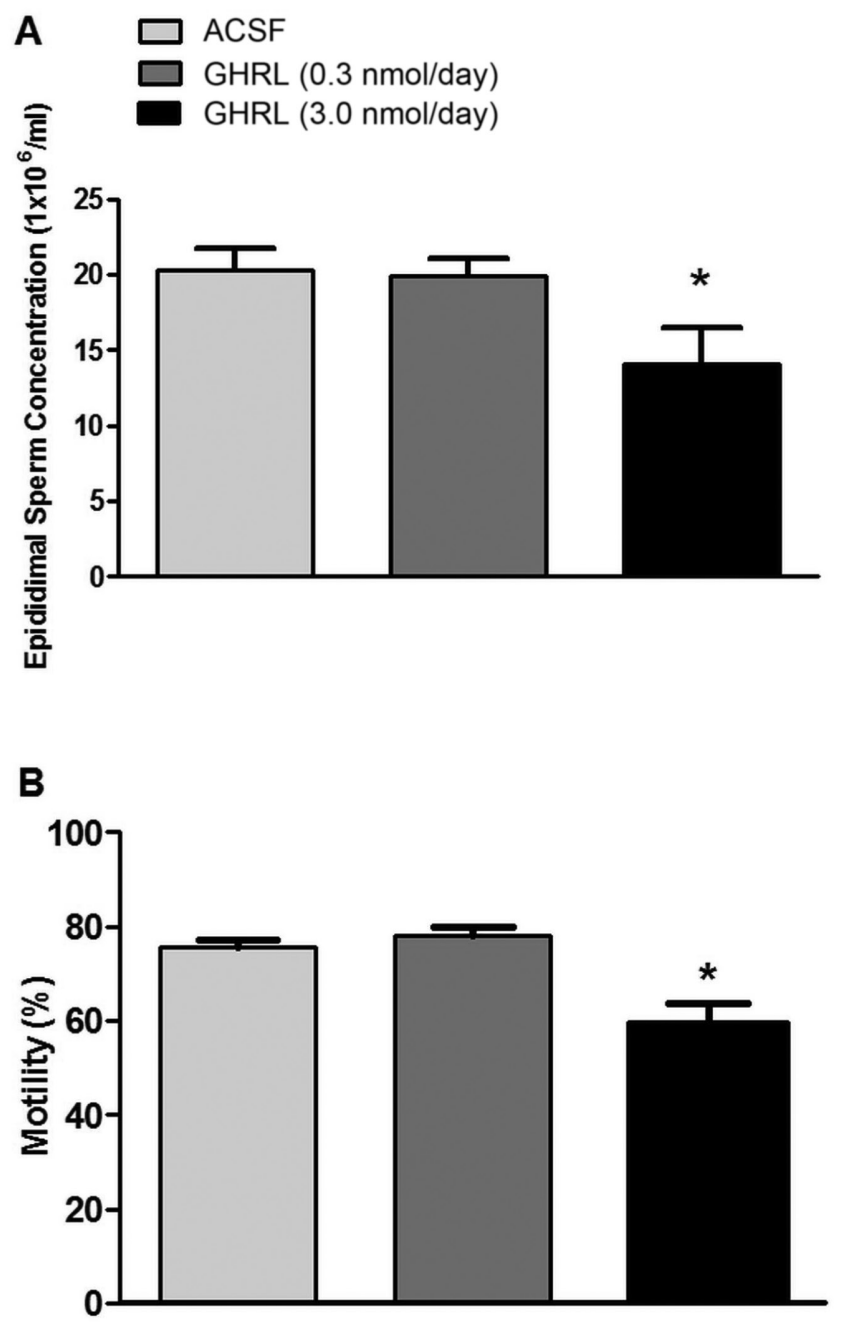

Figure 4 Ghrelin (GHRL) effect on sperm concentration $\left(1 \times 10^{6} / \mathrm{mL}\right)$ (A) and percentage of sperm motility (B) in mice chronically treated for 42 days. Animals were infused into hypothalamus with GHRL or artificial cerebrospinal fluid (ACSF) employing osmotic pumps model $2006(0.15 \mu \mathrm{L} / \mathrm{h}, 42$ days). Results are expressed as mean \pm S.E.M. $n=9-10$ animals/group. *Significant differences in comparison to ACSF animals, $P<0.05$. 
Table 2 Functional activity of caudal epididymis sperm from mice treated for 42 days with artificial cerebrospinal fluid or Ghrelin.

\begin{tabular}{lccc}
\hline & ACSF & GHRL $(0.3 \mathrm{nmol} /$ day $)$ & GHRL $(3.0 \mathrm{nmol} /$ day $)$ \\
\hline Viability $(\%)$ & $83.40 \pm 2.09$ & $79.55 \pm 2.33$ & $78.30 \pm 2.00$ \\
Hypoosmotic swelling test (\%) & $71.91 \pm 2.42$ & $72.91 \pm 2.81$ & $69.05 \pm 3.98$ \\
Acrosomal integrity (\%) & $71.00 \pm 6.23$ & $71.78 \pm 4.36$ & $68.40 \pm 7.37$ \\
\hline
\end{tabular}

Animals were infused into hypothalamus with Ghrelin (GHRL) or artificial cerebrospinal fluid (ACSF) employing osmotic pumps model 2006 $(0.15 \mu \mathrm{L} / \mathrm{h}, 42$ days). Results are expressed as means \pm S.E.M. of the percentage. $n=9-10$ animals/group.

found in the number of Sertoli cells or Leydig cells $(P>0.05)$ (Table 3).

The ANOVA revealed no significant differences on morphometric parameters in mice treated with GHRL when compared with control animals $(P>0.05)$ (Table 4$)$.

No significant differences were found in relative testicle weights $(4.97 \pm 0.18,5.15 \pm 0.13,4.99 \pm 0.17 \mathrm{mg}$ in ACSF, GHRL 0.3 and GHRL $3.0 \mathrm{nmol} /$ day animals, respectively).

Effects of 42-day hypothalamic GHRL administration on mice testicular ultrastructure

As can be seen in Fig. 10, animals treated with GHRL $3.0 \mathrm{nmol} /$ day showed changes in spermatozoa nucleus where chromatin presented an abnormal condensation pattern. In addition, the morphology of the acrosome was altered. Also, a large amount of elongated spermatids can be observed, which is evidenced by the presence of a transient structure called the manchette (microtubules that extend parallel to the major axis of the cell around the posterior part of the nucleus and the upper part of the flagellum).

In addition, no morphological differences were observed in Leydig cells in both control and treated groups.

\section{Discussion}

Studies performed to date regarding the GHRL role in reproductive physiology have been mostly restricted to direct gonadal actions of locally produced GHRL or peptide effects on reproductive hormones, while central effects on functional sperm activity have not been fully elucidated so far. The present work studies the effect of chronic GHRL administration on reproductive hormones concentration, spermatogenesis and sperm quality in mice. We found that hypothalamic GHRL $3.0 \mathrm{nmol} /$ day administration for 42 days decreased caudal epididymal sperm concentration and motility, without affecting sperm viability and parameters related with sperm membrane functionality, such as response to hypoosmotic swelling test and acrosomal integrity. Results also show that GHRL significantly reduced $\mathrm{LH}$ and testosterone plasma levels and, moreover, decreased the percentage of spermatogonia and sperm but increased the intermediate forms, spermatocytes and spermatids after 42 days of treatment. These results provide evidence that chronic central GHRL administration impairs spermatogenesis and that this effect is potentially mediated by inhibition of the HPG axis, since we observed a reduction on plasmatic levels of LH. Function of the HPG axis, and hence of the gonads, depends on strict hormonal control to generate fertilizable gametes and ensure male fertility (Saez 1994, Abou Heif et al. 2010). Increasing evidence suggests that GHRL may participate in such regulatory

A
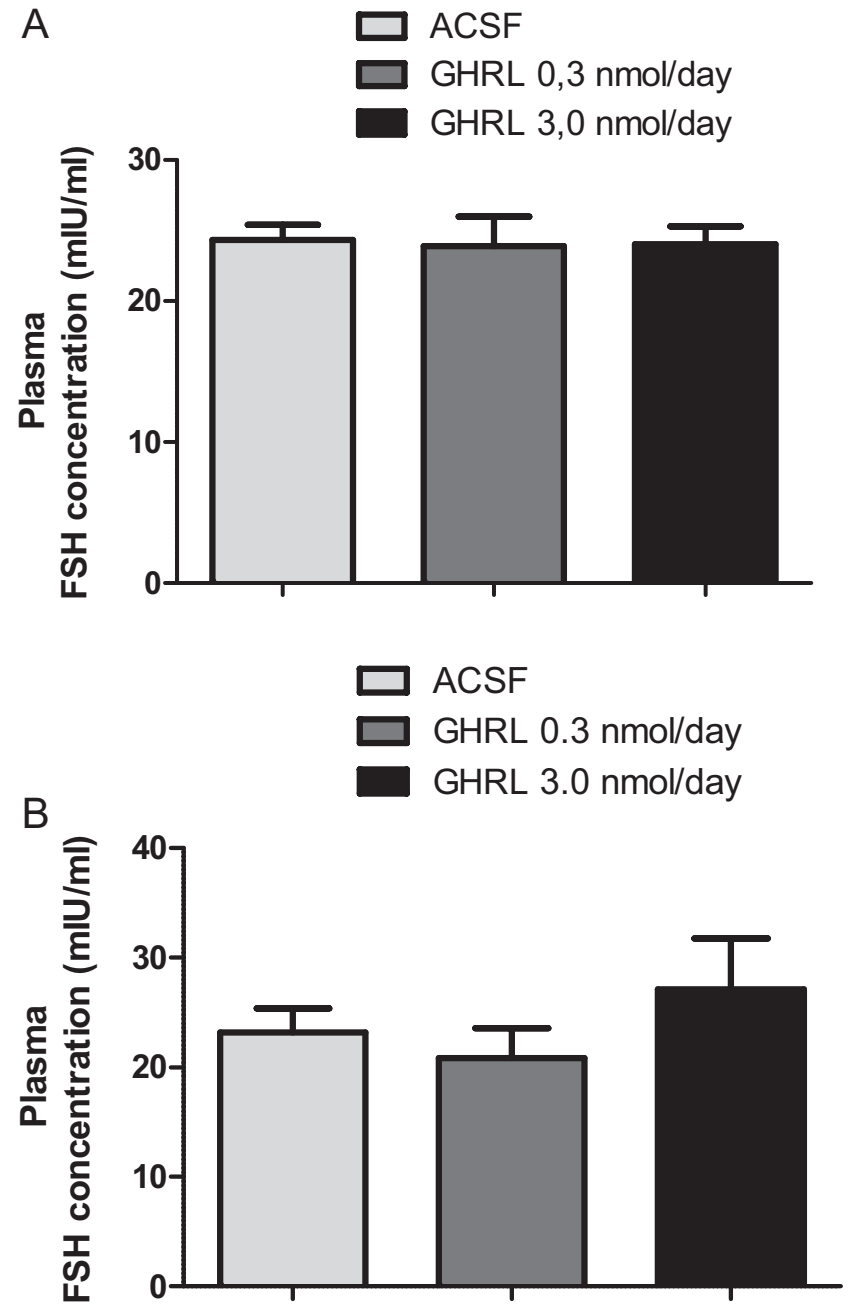

Figure 5 Ghrelin (GHRL) effect on plasma FSH concentration $(\mathrm{mlU} / \mathrm{mL})$ in mice chronically treated for 7 (A) or 42 (B) days. Animals were infused into hypothalamus with GHRL or artificial cerebrospinal fluid (ACSF) employing osmotic pumps model $2006(0.15 \mu \mathrm{L} / \mathrm{h}$, 42 days). Results are expressed as mean \pm S.E.M. $n=5-7$ animals/ group. *Significant differences vs ACSF animals, $P<0.05$. 

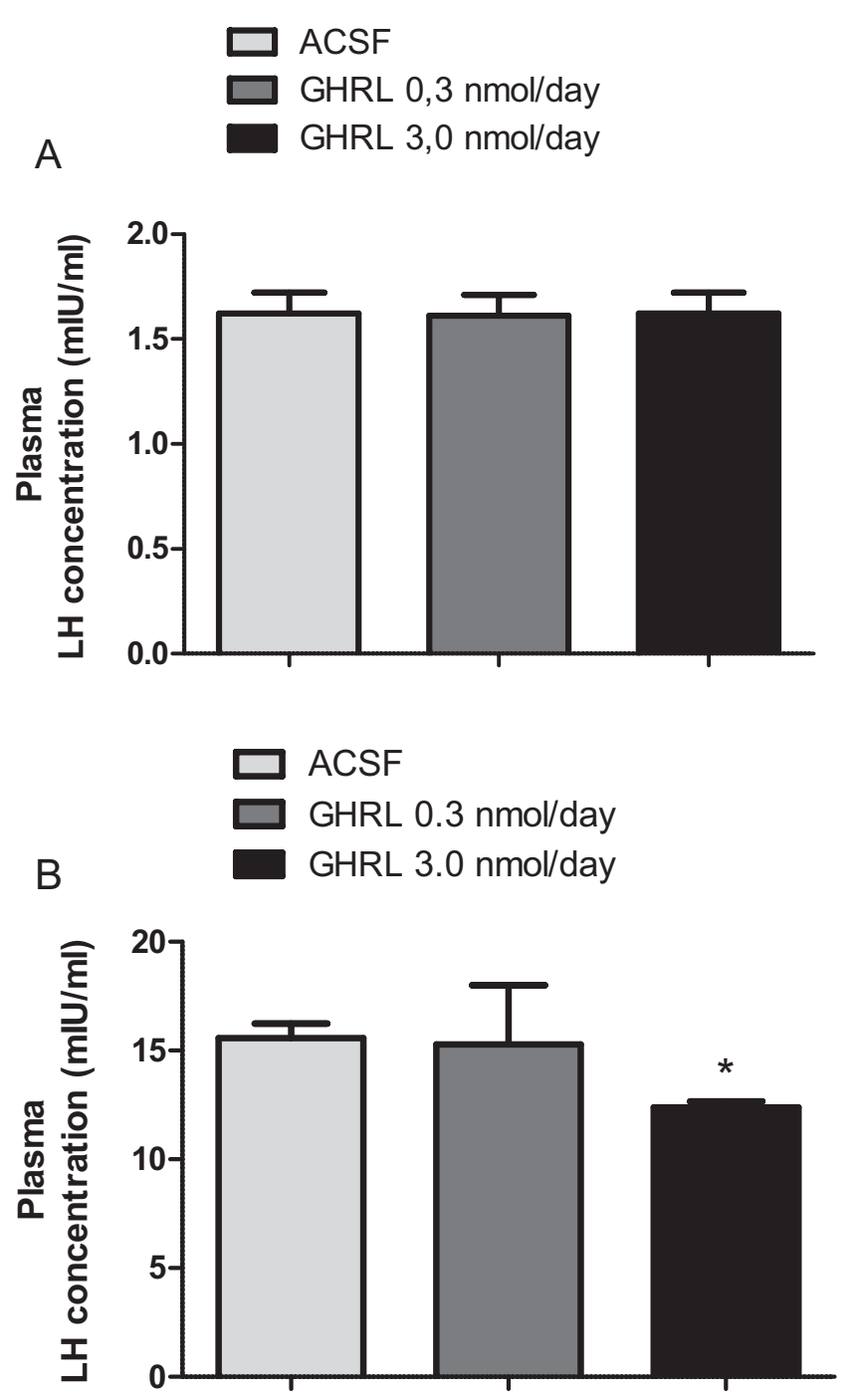

Figure 6 Ghrelin (GHRL) effect on plasma LH concentration (mIU/ $\mathrm{mL}$ ) in mice chronically treated for 7 (A) or 42 (B) days. Animals were infused into hypothalamus with GHRL or artificial cerebrospinal fluid (ACSF) employing osmotic pumps model $2006(0.15 \mu \mathrm{L}$ per hour, 42 days). Results are expressed as mean \pm S.E.M. $n=5-7$ animals/ group. *Significant differences vs ACSF animals, $P<0.05$.

network (Tena-Sempere et al. 2002, Tena-Sempere 2005, 2007). Thus, central GHRL could be regulating the cellular remodeling that occurs as spermatozoa migrate across the epididymis, acting through hormonal control of the HPG axis. Modifications during epididymal transit result in the acquisition of motility and the ability to become capacitated for fertilization (Sullivan et al. 2007). Decreased motility observed in sperm of animals treated with Grh $3.0 \mathrm{nmol} /$ day suggests that GHRL effect could be related to changes in testosterone levels induced by the peptide. These results are supported by high correlation between the concentration of epididymal spermatozoa and testosterone concentration in plasma.
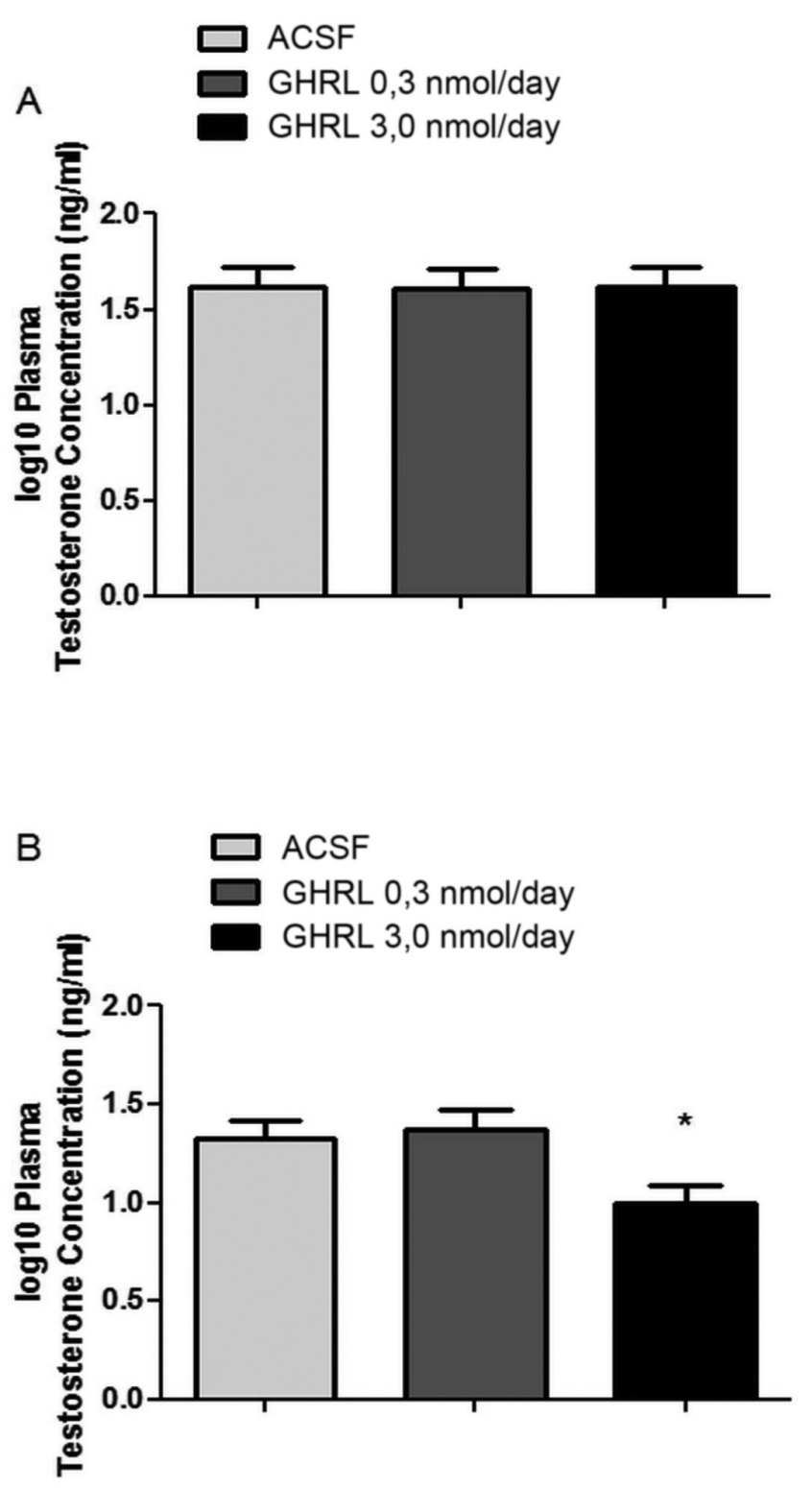

Figure 7 Ghrelin (GHRL) effect on plasma testosterone concentration in mice chronically treated for 7 (A) or 42 (B) days. Animals were infused into hypothalamus with GHRL or artificial cerebrospinal fluid (ACSF) employing osmotic pumps model 2006 (0.15 $\mu \mathrm{L} / \mathrm{h}, 42$ days). Results are expressed as $\log 10$ of the plasma testosterone concentration in $\mathrm{ng} / \mathrm{mL} . n=9-10$ animals/group. *Significant differences vs ACSF animals, $P<0.05$.

Production of fertile spermatozoa is the result of numerous stages of cell differentiation. In the testis, seminiferous tubules and interstitial tissues cooperate in spermatogenic process. Leydig cells are the major interstitial cells and synthesize testosterone for spermatogenesis (Ozawa et al. 2002). It has been demonstrated that intratesticular GHRL injection in vivo is able to inhibit proliferative rate of immature Leydig cells (Barreiro et al. 2004). In this line, subcutaneous injection of GHRL ( $1 \mathrm{nmol} /$ day for 10 days) in adult 

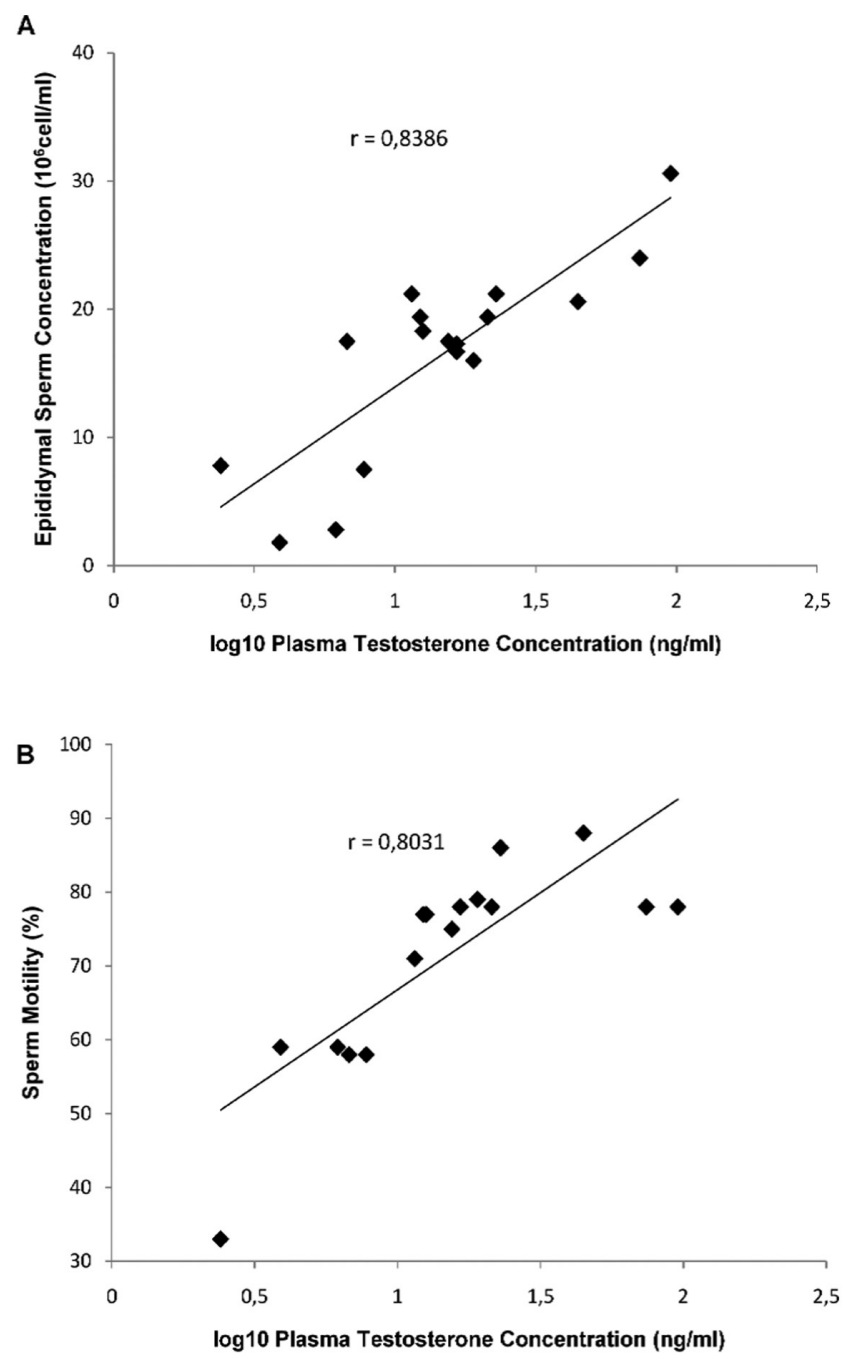

Figure 8 Correlation between $\log 10$ plasma testosterone concentration $(\mathrm{ng} / \mathrm{mL})$ and epididymal sperm concentration (A, spearman rank correlation coefficient $r=0.8386 ; P<0.05$ ) or sperm motility $(B, r=0.8031 ; P<0.05)$ in mice chronically treated for 42 days.

rats showed a decreased number of different spermatic cells as well as Sertoli or Leydig cells and numerous intracellular changes that confirm the suppression of the functional capacity of these cells (Kheradmand et al. 2009). In contrast with this, our results did not show changes either in the number of Sertoli or in Leydig cells, supporting the hypothesis that the changes observed in our experimental model could be a consequence of reproductive hormone regulation by GHRL. Differences in experimental models, administration protocols (acute, sub-chronic or chronic), doses or administration time could be responsible for some inconsistencies in the reports.

It is well known that both $\mathrm{FSH}$ and $\mathrm{LH}$ are necessary for the initiation of spermatogenesis and the establishment of fertility in men (Matthiesson et al. 2006). It has been reported that spermatogonial maturation is largely FSH

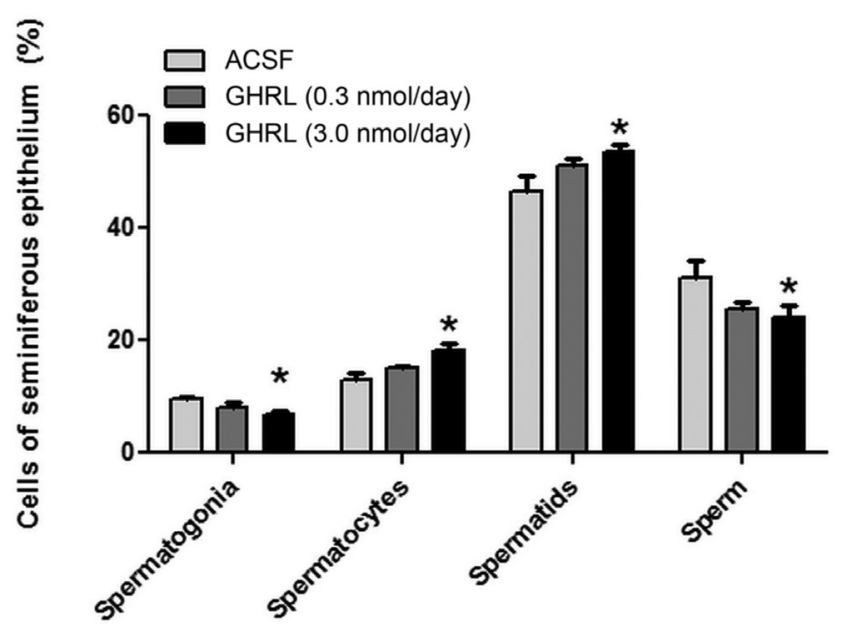

Figure 9 Ghrelin (GHRL) effect on percentage of germ cell types present in the seminiferous epithelium in mice chronically treated for 42 days. Animals were infused with GHRL or artificial cerebrospinal fluid (ACSF) employing osmotic pumps model $2006(0.15 \mu \mathrm{L} / \mathrm{h}$, 42 days). Differential cell counts were gathered counting of at least 20 seminiferous tubules in each slide. Results are expressed in percentage of each cell type as mean \pm S.E.M. $n=5$ animals/group. *Significant differences in comparison to ACSF animals, $P<0.05$.

dependent (Weinbauer et al. 1991, Haywood et al. 2003, Meachem et al. 2005); spermiogenesis appears to be reliant on $\mathrm{LH} /$ intratesticular testosterone (O'Donnell et al. 1994, 1996), whereas spermiation, the process by which mature sperm are released from the Sertoli cell into the lumen of the seminiferous tubule, requires both hormones (Saito et al. 2000). Regarding this, loss of both FSH and $\mathrm{LH}$ action in the GnRHdeficient mouse (Singh et al. 1995) or LH action alone (Lei et al. 2001, Zhang et al. 2001, Ma et al. 2004) results in germ cell arrest at spermatocyte or spermatid stages. Thus, germ cell development in the mouse can be completed in the absence of FSH but not androgen action (Matthiesson et al. 2006). Such data support results observed in our experiments about spermatid retention in relation to the overall reduction of sperm production caused by low plasmatic testosterone concentration dependent on LH stimulation. Therefore, current findings are similar to results previously discussed, and GHRL effects on reproductive axis seem

Table 3 Ghrelin effect on number of Leydig and Sertoli cells in mice chronically treated for 42 days.

\begin{tabular}{lccc}
\hline & ACSF & $\begin{array}{c}\text { GHRL } \\
(0.3 \mathrm{nmol} / \text { day })\end{array}$ & $\begin{array}{c}\text { GHRL } \\
(3.0 \mathrm{nmol} / \text { day })\end{array}$ \\
\hline Leydig cells & $65.60 \pm 7.15$ & $78.40 \pm 6.33$ & $70.20 \pm 7.77$ \\
Sertoli cells & $11.80 \pm 1.20$ & $11.20 \pm 2.96$ & $12.60 \pm 1.83$ \\
\hline
\end{tabular}

Animals were infused into hypothalamus with Ghrelin (GHRL) or artificial cerebrospinal fluid (ACSF) employing osmotic pumps model $2006(0.15 \mu \mathrm{L} / \mathrm{h}, 42$ days). Differential cell counts were gathered counting of at least 20 seminiferous tubules in each slide. Results are expressed as mean \pm S.E.M. $n=5$ animals/group. 
Table 4 Ghrelin effect on the morphometry of mice testis chronically treated for 42 days.

\begin{tabular}{lccc}
\hline & ACSF & GHRL $(0.3 \mathrm{nmol} /$ day $)$ & GHRL $(3.0 \mathrm{nmol} /$ day $)$ \\
\hline Seminiferous tubular diameter $(\mu \mathrm{m})$ & $216.23 \pm 7.76$ & $206.23 \pm 4.60$ & $208.02 \pm 12.28$ \\
Seminiferous epithelium height $(\mu \mathrm{m})$ & $66.83 \pm 1.47$ & $62.76 \pm 3.39$ & $63.68 \pm 1.86$ \\
\hline
\end{tabular}

Animals were infused with Ghrelin (GHRL) or artificial cerebrospinal fluid (ACSF) employing osmotic pumps model 2006 (0.15 $\mu \mathrm{L}$ per hour, 42 days). Testicular morphometry analyzes were assessed as seminiferous tubular diameter $(\mu \mathrm{m})$ and the epithelium height ( $\mu \mathrm{m})$ taking into account 50 round or nearly round seminiferous tubules from each mouse. Results are expressed as mean \pm S.E.M. $n=5$ animals/group.

to be more likely related to reduce circulating levels of $\mathrm{LH}$ rather than FSH levels.

It is well known that spermatogenesis is a complex process that requires the correct interplay and timing of cellular modifications to produce functional and motile sperm. During this process, spermatogonia undergoes a series of transformations, culminating with the hypercompaction of DNA into the sperm head by replacing histones with a specialized DNAbinding protein, protamine (Kanippayoor et al. 2013). Ultrastructural observations of treated animals in our experiments showed an abnormal pattern of chromatin condensation and altered morphology of the acrosome. These alterations could be another possible alternative to explain the changes observed in motility in our research.

On the other hand, hypothalamic GHRL administration for 7 days did not modify spermatogenesis, neither in number nor in functional activity, expressed as

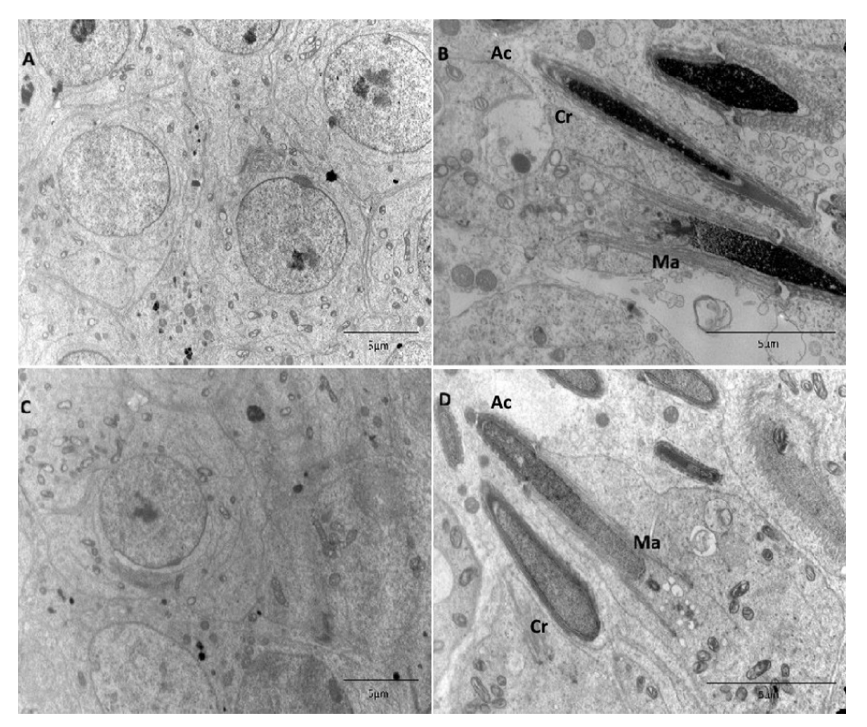

Figure 10 Electron micrographs from seminiferous tubules in mice chronically treated for 42 days. Animals were infused into hypothalamus with Ghrelin (GHRL $3.0 \mathrm{nmol} /$ day - C and D) or artificial cerebrospinal fluid (ACSF, A and B) employing osmotic pumps model $2006(0.15 \mu \mathrm{L} / \mathrm{h}, 42$ days). (A and C) Sertoli cells (scale bar: $5 \mu \mathrm{m}$ ). (B and D) Spermatid and spermatozoon (scale bar: $5 \mu \mathrm{m}$ ). Panel D vs B: GHRL-infused animals (D) showed changes in spermatozoa nucleus where chromatin (CR) presented an abnormal condensation pattern; the morphology of the acrosome (Ac) was altered; a large amount of elongated spermatids can be observed, which is evidenced by the presence of a transient structure called the manchette (Ma). Panel C vs A: no morphological differences were observed in Leydig cells. $n$ : 3-5 animals/group. motility, viability, response to hypoosmotic swelling test and functionally intact sperm membrane for the correct performance of this gamete. As stated before, epididymal maturation, necessary for the presentation of straight morphology and the acquisition of motility, is an androgen-dependent process (Fernandez et al. 2008) and treatment for 7 days was not enough to produce significant changes in testosterone levels, consequently, the quality of the gametes was unaffected.

As GHRL is an orexigenic peptide, we daily measured body weight and food intake in order to minimize potential bias of major differences in body weight that could affect reproductive endpoints under analysis. Results presented here confirm that GHRL increases food intake, which was previously demonstrated in some reports (Tschöp et al. 2000, Nakazato et al. 2001, Wren et al. 2001); however, the effect did not last beyond the fifth day of treatment. These results are in line with other authors that have shown that chronic elevation of GHRL in the hypothalamus produces an increase in food intake that leads to an increase in body weight, but this effect seems to be only transient and normalizes after a few weeks (Qi et al. 2015). In addition, there are some authors who state that GHRL is not a critical orexigenic factor, based on the observation that mice deficient in either ghrelin or its receptor exhibit normal feeding behavior (Sun et al. 2003, 2004, Wortley et al. 2004, Sato et al. 2008). According to this, chronic effects observed on reproductive parameters cannot be attributed to this variable.

In conclusion, this study provides new evidence about deleterious effect of centrally administered GHRL on functional sperm activity and sex steroids production and suggests that this effect is mediated through hypothalamus by inhibition of HPG axis. However, futures studies are necessary to contribute to the understanding of the molecular mechanisms of GHRL actions.

\section{Declaration of interest}

The authors declare that there is no conflict of interest that could be perceived as prejudicing the impartiality of the research reported.

\section{Funding}

This work was supported by grants from CONICET (PIP_6132761, 11220130100380 CO), SECyT-UNC (05/H383), 
the Swedish Research Foundation (VR) and the Swedish Brain Research Foundation.

\section{Acknowledgments}

The authors thank Grupo Pilar - GEPSA for the donation of the animals' pelleted food. They also would like to thank Dr Paul Hobson, native speaker, for manuscript revision. Ana Carolina Martini, Marina Ponzio and Valeria Paola Carlini: Established Investigator from CONICET. María Belén Poretti and Eugenia Luque: CONICET Fellowship.

\section{References}

Abou Heif H, Deif M \& Abdel Aziz H 2010 Effect of food restriction on ghrelin in adult male rats and its relation to male reproductive hormones. Andrologia 42 97-105. (https://doi.org/10.1111/j.14390272.2009.00962.x)

Barreiro ML \& Tena-Sempere M 2004 Ghrelin and reproduction: a novel signal linking energy status and fertility? Molecular and Cellular Endocrinology 226 1-9. (https://doi.org/10.1016/j.mce.2004.07.015)

Barreiro ML, Gaytan F, Caminos JE, Pinilla L, Casanueva FF, Aguilar E, Dieguez C \& Tena-Sempere M 2002 Cellular location and hormonal regulation of ghrelin expression in rat testis. Biology of Reproduction $\mathbf{6 7}$ 1768-1776. (https://doi.org/10.1095/biolreprod.102.006965)

Barreiro ML, Suominen JS, Gaytan F, Pinilla L, Chopin LK, Casanueva FF, Dieguez C, Aguilar E, Toppari J \& Tena-Sempere M 2003 Developmental, stage-specific, and hormonally regulated expression of growth hormone secretagogue receptor messenger RNA in rat testis. Biology of Reproduction 68 1631-1640. (https://doi.org/10.1095/ biolreprod.102.008862)

Barreiro ML, Gaytan F, Castellano JM, Suominen JS, Roa J, Gaytan M, Aguilar E, Dieguez C, Toppari J \& Tena-Sempere M 2004 Ghrelin inhibits the proliferative activity of immature Leydig cells in vivo and regulates stem cell factor messenger ribonucleic acid expression in rat testis. Endocrinology 145 4825-4834. (https://doi.org/10.1210/en.2004-0732)

Broglio F, Gottero C, Arvat E \& Ghigo E 2003 Endocrine and nonendocrine actions of ghrelin. Hormone Research 59 109-117. (https:// doi.org/10.1159/000069065)

Casanueva FF \& Dieguez C 1999 Neuroendocrine regulation and actions of leptin. Frontiers in Neuroendocrinology 20 317-363. (https://doi. org/10.1006/frne.1999.0187)

Clermont Y \& Trott M 1969 Duration of the cycle of the seminiferous epithelium in the mouse and hamster determined by means of 3H-thymidine and radioautography. Fertility and Sterility 20 805-817. (https://doi.org/10.1016/S0015-0282(16)37153-9)

Diaz de Barboza G, Rodriguez V, Ponce R, Theiler G, Maldonado C \& Tolosa de Talamoni N 2014 Association of cellular and molecular alterations in Leydig cells with apoptotic changes in germ cells from testes of Graomys griseoflavusxGraomys centralis male hybrids. Acta Histochemica 116 1037-1045. (https://doi.org/10.1016/j.acthis.2014.04.007)

Duan W, Liu C, Wu H, Chen C, Zhang T, Gao P, Luo X, Yu Z \& Zhou Z 2014 Effects of exposure to extremely low frequency magnetic fields on spermatogenesis in adult rats. Bioelectromagnetics 35 58-69. (https:// doi.org/10.1002/bem.21816)

Fernandez CD, Porto EM, Arena AC \& Kempinas Wde G 2008 Effects of altered epididymal sperm transit time on sperm quality. International Journal of Andrology 31 427-437. (https://doi.org/10.1111/j.13652605.2007.00788.x)

Fernandez-Fernandez R, Tena-Sempere M, Aguilar E \& Pinilla L 2004 Ghrelin effects on gonadotropin secretion in male and female rats. Neuroscience Letters 362 103-107. (https://doi.org/10.1016/j. neulet.2004.03.003)

Fiol de Cuneo M, Ruiz RD, Ponce A, Maldonado X \& Lacuara JL 1994 Time-related changes in functional activity of mouse spermatozoa during in vitro or in vivo incubation. Journal of Experimental Animal Science 36 189-200.
Franca LR, Ogawa T, Avarbock MR, Brinster RL \& Russell LD 1998 Germ cell genotype controls cell cycle during spermatogenesis in the rat. Biology of Reproduction 59 1371-1377. (https://doi.org/10.1095/ biolreprod59.6.1371)

Fraser LR 1993 In vitro capacitation and fertilization. Methods in Enzymology 225 239-253. (https://doi.org/10.1016/0076-6879(93)25016-U)

Garcia MC, Lopez M, Alvarez CV, Casanueva F, Tena-Sempere M \& Dieguez C 2007 Role of ghrelin in reproduction. Reproduction 133 531-540. (https://doi.org/10.1530/REP-06-0249)

Gaytan F, Barreiro ML, Caminos JE, Chopin LK, Herington AC, Morales C, Pinilla L, Paniagua R, Nistal M, Casanueva FF et al. 2004 Expression of ghrelin and its functional receptor, the type 1a growth hormone secretagogue receptor, in normal human testis and testicular tumors. Journal of Clinical Endocrinology and Metabolism 89 400-409. (https:// doi.org/10.1210/jc.2003-031375)

Gnanapavan S, Kola B, Bustin SA, Morris DG, McGee P, Fairclough P, Bhattacharya S, Carpenter R, Grossman AB \& Korbonits M 2002 The tissue distribution of the mRNA of ghrelin and subtypes of its receptor, GHS-R, in humans. Journal of Clinical Endocrinology and Metabolism 87 2988. (https://doi.org/10.1210/jcem.87.6.8739)

Guan XM, Yu H, Palyha OC, McKee KK, Feighner SD, Sirinathsinghji DJ, Smith RG, Van der Ploeg LH \& Howard AD 1997 Distribution of mRNA encoding the growth hormone secretagogue receptor in brain and peripheral tissues. Brain Research: Molecular Brain Research 48 23-29. (https://doi.org/10.1016/S0169-328X(97)00071-5)

Haywood M, Spaliviero J, Jimemez M, King NJ, Handelsman DJ \& Allan CM 2003 Sertoli and germ cell development in hypogonadal (hpg) mice expressing transgenic follicle-stimulating hormone alone or in combination with testosterone. Endocrinology 144 509-517. (https:// doi.org/10.1210/en.2002-220710)

Horvath TL, Diano S, Sotonyi P, Heiman M \& Tschop M 2001 Minireview: ghrelin and the regulation of energy balance - a hypothalamic perspective. Endocrinology 142 4163-4169. (https://doi.org/10.1210/ endo.142.10.8490)

Kanippayoor RL, Alpern JH \& Moehring AJ 2013 Protamines and spermatogenesis in Drosophila and Homo sapiens: a comparative analysis. Spermatogenesis 3 e24376. (https://doi.org/10.4161/ spmg.24376)

Kheradmand A, Roshangar L \& Taati M 2009 The role of ghrelin on the morphometry and intracellular changes in the rat testis. Tissue and Cell 41 105-111. (https://doi.org/10.1016/j.tice.2008.07.006)

Kojima M, Hosoda H, Date Y, Nakazato M, Matsuo H \& Kangawa K 1999 Ghrelin is a growth-hormone-releasing acylated peptide from stomach. Nature 402 656-660. (https://doi.org/10.1038/45230)

Kojima M, Hosoda H \& Kangawa K 2001 Purification and distribution of ghrelin: the natural endogenous ligand for the growth hormone secretagogue receptor. Hormone Research 56 (Supplement 1) 93-97. (https://doi.org/10.1159/000048143)

Lei ZM, Mishra S, Zou W, Xu B, Foltz M, Li X \& Rao CV 2001 Targeted disruption of luteinizing hormone/human chorionic gonadotropin receptor gene. Molecular Endocrinology 15 184-200. (https://doi. org/10.1210/mend.15.1.0586)

Ma X, Dong Y, Matzuk MM \& Kumar TR 2004 Targeted disruption of luteinizing hormone beta-subunit leads to hypogonadism, defects in gonadal steroidogenesis, and infertility. PNAS 101 17294-17299. (https://doi.org/10.1073/pnas.0404743101)

Makler A 1980 The improved ten-micrometer chamber for rapid sperm count and motility evaluation. Fertility and Sterility 33 337-338. (https:// doi.org/10.1016/S0015-0282(16)44606-6)

Matthiesson KL, McLachlan RI, O'Donnell L, Frydenberg M, Robertson DM, Stanton PG \& Meachem SJ 2006 The relative roles of follicle-stimulating hormone and luteinizing hormone in maintaining spermatogonial maturation and spermiation in normal men. Journal of Clinical Endocrinology and Metabolism 91 3962-3969. (https://doi. org/10.1210/jc.2006-1145)

Meachem SJ, Stanton PG \& Schlatt S 2005 Follicle-stimulating hormone regulates both Sertoli cell and spermatogonial populations in the adult photoinhibited Djungarian hamster testis. Biology of Reproduction 72 1187-1193. (https://doi.org/10.1095/biolreprod.104.039321)

Munro CJ \& Lasley BL 1988 Non-radiometric methods for immunoassay of steroid hormones. Progress in Clinical and Biological Research 285 289-329. 
Munro CJ, Stabenfeldt GH, Cragun JR, Addiego LA, Overstreet JW \& Lasley BL 1991 Relationship of serum estradiol and progesterone concentrations to the excretion profiles of their major urinary metabolites as measured by enzyme immunoassay and radioimmunoassay. Clinical Chemistry 37 838-844. (https://doi.org/10.1002/ajp.22625)

Nakazato M, Murakami N, Date Y, Kojima M, Matsuo H, Kangawa K \& Matsukura S 2001 A role for ghrelin in the central regulation of feeding. Nature 409 194-198. (https://doi.org/10.1038/35051587)

O'Donnell L, McLachlan RI, Wreford NG \& Robertson DM 1994 Testosterone promotes the conversion of round spermatids between stages VII and VIII of the rat spermatogenic cycle. Endocrinology $\mathbf{1 3 5}$ 2608-2614. (https://doi.org/10.1210/endo.135.6.7988449)

O'Donnell L, McLachlan RI, Wreford NG, de Kretser DM \& Robertson DM 1996 Testosterone withdrawal promotes stage-specific detachment of round spermatids from the rat seminiferous epithelium. Biology of Reproduction 55 895-901. (https://doi.org/10.1095/biolreprod55.4.895)

Ozawa N, Goda N, Makino N, Yamaguchi T, Yoshimura Y \& Suematsu M 2002 Leydig cell-derived heme oxygenase-1 regulates apoptosis of premeiotic germ cells in response to stress. Journal of Clinical Investigation 109 457-467. (https://doi.org/10.1172/JCI0213190)

Paxinos G \& Franklin K 2001 The Mouse Brain in Stereotaxic Coordinates. San Diego, CA, USA: Academic.

Puechagut P, Martini A, Stutz G, Santillán M, Luque E, de Cuneo MF, Ruiz R \& Vincenti L 2012 Reproductive performance and fertility in male and female adult mice chronically treated with hexarelin. Reproduction, Fertility and Development 24 451-460. (https://doi.org/10.1071/ RD11009)

Qi Y, Inoue K, Fu M, Inui A \& Herzog H 2015 Chronic overproduction of ghrelin in the hypothalamus leads to temporal increase in food intake and body weight. Neuropeptides 50 23-28. (https://doi.org/10.1016/j. npep.2015.02.002)

Ruiz R, Fiol de Cuneo M, Santillán M, Ponce A, Vincenti L, Lacuara J \& Stutz G 1996 Hypoosmotic swelling test (HOST) for assessing the integrity of the mouse sperm membrane and its relationship with other functional parameters. Effects of 2-deoxyadenosine. Journal of Experimental Animal Science 37 149-157.

Saez JM 1994 Leydig cells: endocrine, paracrine, and autocrine regulation. Endocrine Reviews 15 574-626. (https://doi.org/10.1210/edrv-15-5-574)

Saito K, O'Donnell L, McLachlan RI \& Robertson DM 2000 Spermiation failure is a major contributor to early spermatogenic suppression caused by hormone withdrawal in adult rats. Endocrinology 141 2779-2785. (https://doi.org/10.1210/endo.141.8.7628)

Sato T, Kurokawa M, Nakashima $Y$, Ida T, Takahashi T, Fukue $\mathrm{Y}$, Ikawa $\mathrm{M}$, Okabe M, Kangawa K \& Kojima M 2008 Ghrelin deficiency does not influence feeding performance. Regulatory Peptides 145 7-11. (https:// doi.org/10.1016/j.regpep.2007.09.010)

Singh J, O'Neill C \& Handelsman DJ 1995 Induction of spermatogenesis by androgens in gonadotropin-deficient (hpg) mice. Endocrinology 136 5311-5321. (https://doi.org/10.1210/endo.136.12.7588276)

Sullivan R, Frenette G \& Girouard J 2007 Epididymosomes are involved in the acquisition of new sperm proteins during epididymal transit. Asian Journal of Andrology 9 483-491. (https://doi.org/10.1111/j.17457262.2007.00281.x)
Sun Y, Ahmed S \& Smith RG 2003 Deletion of ghrelin impairs neither growth nor appetite. Molecular and Cellular Biology 23 7973-7981. (https://doi.org/10.1128/MCB.23.22.7973-7981.2003)

Sun Y, Wang P, Zheng H \& Smith RG 2004 Ghrelin stimulation of growth hormone release and appetite is mediated through the growth hormone secretagogue receptor. PNAS 101 4679-4684. (https://doi.org/10.1073/ pnas.0305930101)

Tena-Sempere M 2005 Ghrelin: novel regulator of gonadal function. Journal of Endocrinological Investigation 28 26-29.

Tena-Sempere M 2007 Ghrelin and reproduction: ghrelin as novel regulator of the gonadotropic axis. Vitamins and Hormones 77 285-300. (https:// doi.org/10.1016/S0083-6729(06)77012-1)

Tena-Sempere M \& Barreiro ML 2002 Leptin in male reproduction: the testis paradigm. Molecular and Cellular Endocrinology 188 9-13. (https:// doi.org/10.1016/S0303-7207(02)00008-4)

Tena-Sempere M, Barreiro ML, Gonzalez LC, Gaytan F, Zhang FP, Caminos JE, Pinilla L, Casanueva FF, Dieguez C \& Aguilar E 2002 Novel expression and functional role of ghrelin in rat testis. Endocrinology 143 717-725. (https://doi.org/10.1210/endo.143.2.8646)

Tschöp M, Smiley DL \& Heiman ML 2000 Ghrelin induces adiposity in rodents. Nature 407 908-913. (https://doi.org/10.1038/35038090)

Weinbauer GF, Behre HM, Fingscheidt U \& Nieschlag E 1991 Human follicle-stimulating hormone exerts a stimulatory effect on spermatogenesis, testicular size, and serum inhibin levels in the gonadotropin-releasing hormone antagonist-treated nonhuman primate (Macaca fascicularis). Endocrinology 129 1831-1839. (https://doi. org/10.1210/endo-129-4-1831)

Wortley KE, Anderson KD, Garcia K, Murray JD, Malinova L, Liu R, Moncrieffe M, Thabet K, Cox HJ, Yancopoulos GD et al. 2004 Genetic deletion of ghrelin does not decrease food intake but influences metabolic fuel preference. PNAS 101 8227-8232. (https://doi. org/10.1073/pnas.0402763101)

Wren AM, Seal LJ, Cohen MA, Brynes AE, Frost GS, Murphy KG, Dhillo WS, Ghatei MA \& Bloom SR 2001 Ghrelin enhances appetite and increases food intake in humans. Journal of Clinical Endocrinology and Metabolism 86 5992. (https://doi.org/10.1210/jcem.86.12.8111)

Yelian FD \& Dukelow WR 1992 Effects of a DNA-specific fluorochrome, Hoechst 33258, on mouse sperm motility and fertilizing capacity. Andrologia 24 167-170. (https://doi.org/10.1111/j.1439-0272.1992. tb02632.x)

Zhang FP, Poutanen M, Wilbertz J \& Huhtaniemi I 2001 Normal prenatal but arrested postnatal sexual development of luteinizing hormone receptor knockout (LuRKO) mice. Molecular Endocrinology 15 172-183. (https://doi.org/10.1210/mend.15.1.0582)

Received 29 August 2017

First decision 29 September 2017

Revised manuscript received 27 April 2018

Accepted 22 May 2018 